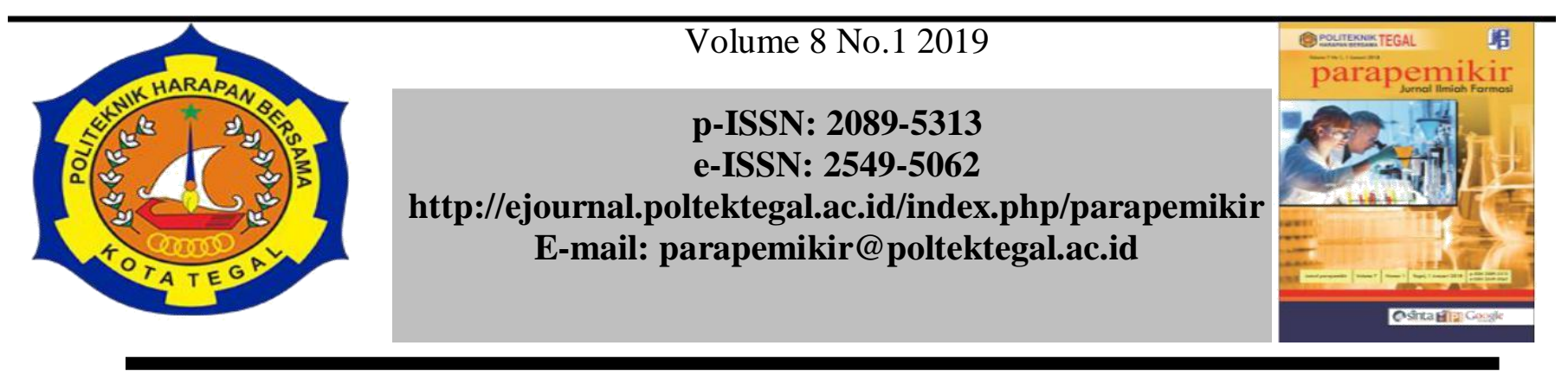

\title{
AKTIVITAS ANTIBAKTERI SEDIAAN FOOT SANITIZER SPRAY YANG MENGANDUNG EKSTRAK BIJI KOPI DAN JAHE
}

\author{
Joko Santoso ${ }^{1}$, Aldi Budi Riyanta ${ }^{2}$ \\ ${ }^{12}$ Prodi D3 Farmasi Politeknik Harapan Bersama \\ Email : Jk23sm@gmail.com \\ aldibudiriyanta@yahoo.co.id
}

\section{Article Info}

Article history:

Received july 2017

Received in

revised form

July 2017

Accepted August 2017

Available online

January 2018

Kata kunci: Foot sanitizer spray,

Kopi, jahe,

Antibakteri,

S.epidermis

\section{Keywords: foot}

sanitizer spray,

Coffee, Ginger,

Antibacterial,

S.epidermis

\begin{abstract}
Abstrak
Aroma kaki yang tidak sedap menjadi salah satu masalah sebagian orang yang disebabkan keringat bercampur bakteri dan kondisi lembab. Bakteri S.epidermis merupakan bakteri yang tumbuh dalam keadaan tersebut. Kopi dan jahe mempunyai manfaat yang sinergis dengan aroma yang kuat dan aktivitas antibakteri sehingga disukai. Penelitian ini dimaksudkan untuk mengetahui daya hambat antibakteri footsanitizer dari kombinasi kopi dan jahe, serta menghasilkan sifat fisik yang baik. Maserasi dengan pelarut ethanol $70 \%$ digunakan pada penelitian ini. Ekstrak yang didapat berupa ekstrak cair yang selanjutnya dibuat dalam sediaan foot sanitizer. Evaluasi sediaan yang dilakukan antara lain uji organoleptis, uji $\mathrm{pH}$, kerjernihan, berat jenis, viskositas dan uji aktivitas antibakteri terhadap bakteri S.epidermis. Hasil penelitian menunjukkan bahwa sediaan foot sanitizer memiliki sifat fisik cairan jernih, berbau khas ekstrak, rasa dingin dan dengan $\mathrm{pH}$ sesuai dengan syarat sediaan topikal. Formula III memiliki berat jenis tertinggi dengan $0,954 \mathrm{~g} / \mathrm{ml}$ dan berturutturut formula II dan formula I dengan hasil $0,9452 \mathrm{~g} / \mathrm{ml}$, Viskositas tertinggi dengan nilai 2,3013 $\mathrm{Cp}$ dan menghasilkan Aktivitas antibakteri paling tinggi sebesar 0,348 $\mathrm{cm}^{2}$.
\end{abstract}

\footnotetext{
Abstract

The smell of feet is one of the problems of some people caused by sweat mixed with bacteria and moist conditions. S.epidermis bacteria are bacteria that grow in these conditions. Coffee and ginger have synergistic benefits with strong aroma and antibacterial activity so it is preferred. This study is focused to determine the antibacterial inhibition of footsanitizer formula from a combination of coffee and ginger, and produce good physical properties. Maseration with $70 \%$ ethanol solvent was used in this study and then formulated. The formulation was evaluated for physical properties such as organoleptic test, pH test, clarity, specific gravity, viscosity. Antibacterial activity test using the well method on S.epidermis. The results showed that foot sanitizer formula had physical properties of clear liquid, distinctive smell of extract, cold taste and $\mathrm{pH}$ in accordance with the requirements of topical formulations. Formula III has the highest specific gravity, viscosity and with $0.954 \mathrm{~g} /$ $\mathrm{ml}$ and $2.3013 \mathrm{Cp}$. The highest antibacterial activity with $0.348 \mathrm{~cm}^{2}$
}

(C)2018PoliteknikHarapanBersamaTegal

\begin{tabular}{lr}
\hline Alamat korespondensi: & \\
Prodi DIII Farmasi Politeknik Harapan Bersama Tegal & \\
Gedung A Lt.3. Kampus 1 & \\
Jl. Mataram No. 09 Kota Tegal, Kodepos 52122 & p-ISSN: 2089-5313 \\
Telp. (0283) 352000 & e-ISSN: 2549-5062 \\
E-mail: parapemikir_poltek@yahoo.com &
\end{tabular}




\section{Pendahuluan}

Aroma tidak sedap yang ditimbulkan oleh bakteri yang berkembang biak dalam lingkungan lembab. Bakteri seperti Staphylococcus adalah salah satu penyebab timbulnya bau kaki yang bekerja dengan cara mendegradasi leusin yang dihasilkan oleh keringat. Sehingga terbentuk asam isovalerat yang merupakan suatu asam lemak penyebab bau kaki ${ }^{1}$.

Kopi memiliki aroma yang khas dan dapat diterima oleh berbagai kalangan masyarakat. Secara tradisional aroma kopi biasanya digunakan untuk mengharumkan ruangan. (Riyanta dan Febriyanti, 2018 melaporkan bahwa kandungan kopi dalam sediaan foot sanitizer mampu menghilangkan bau pada kaki. Kopi yang memiliki kandungan air dibawah12\% dan mempunyai kemiripan dengan karbon aktif sebagai penyerap (adsorben) berfungsi sebagai detoks untuk menyerap racun ${ }^{3}$.

Jahe secara tradisional digunakan dalam berbagai macam pengobatan salah satunya pembersih kulit dalam bentuk lulur 2. Jahe memiliki kandungan senyawa flavonoid dan fenol berfungsi sebagai antimikroba. Mikroba dihambat oleh fenol bekerja dengan menghancurkan dinding sel yang akan berakibat lisis sel mikrobanya (terjadi penghambatan sintesis dinding sel bakteri). Permeabilitas membrane sel bakteri menurun hingga terjadi kebocoran sehingga isi sel keluar dan mengalami denaturasi protein. Kerja sel terhambat oleh karena metabolismenya rusak ${ }^{\mathbf{1 2}}$.

Foot sanitizer adalah cairan pembersih kaki dengan alcohol sebagai bahan dasarnya yang digunakan untuk membunuh mikroorganisme tanpa proses pembilasan air. Sediaan ini dirancang untuk mampu membunuh bakteri dengan cepat yang terdapat dipermukaan kulit. Foot sanitizer sering digunakan ketika keadaan darurat tanpa bergantung adanya air. Food and Drug Administration USA (FDA) mengemukakan bahwa sediaan foot sanitizer dapat mematikan bakteri dengan waktu kurang dari 30 menit ${ }^{4}$. Center for Disease Control (CDC) membagi menjadi dua kelompok yaitu foot sanitizer mengandung alkohol dan tidak mengandung alkohol. Foot sanitizer dengan kandungan alkohol antara 60-95 $\%$ berefek anti mikroba yang baik dibandingkan dengan tanpa alkohol.

Penelitian ini memiliki tujuan untuk mengetahui pengaruh dan kemampuan sediaan foot sanitizer ekstrak kopi dan jahe terhadap aktivitas antibakteri S.epidermis
II. Metodologi Penelitian

1. Bahan dan Alat Penelitiam Bahan

Pada penelitian ini bahan yang digunakan antara lain biji kopi yang diserbukkan dan rimpang jahe yang dibeli di Pasar Pagi Kota Tegal, alkohol $70 \%$, methyl paraben, gliserin, aquadest (Brataco Chemical) media NA, media MHA, media BHI dan bakteri S.epidermis (Universitas Muhammadiyah Purwokerto).

Alat

Alat-alat yang digunakan pada penelitian ini yaitu maserator (Bejana maserasi), rotary evaporator (RE 100-Pro), cawan porselain, bekker glass, batang pengaduk, gelas ukur, waterbath, serbet, termometer, piknometer (Pyrex), viskometer ostwald, botol spray.

2. Cara Kerja

a. Pembuatan serbuk

Tahap pertama yang dilakukan yaitu dengan pengumpulan bahan baku yang kemudian disortasi agar di dapat sampel yang baik. Biji kopi dan jahe yang sudah kering selanjutnya di haluskan untuk mendapatkan masa serbuk.

b. Pembuatan Ekstrak Jahe dan Biji

\section{Kopi}

Pembuatan ekstrak dilakukan dengan metode maserasi. Serbuk kopi dan serbuk jahe masing-masing disiapkan dalam bejana. Serbuk direndam dengan etanol $70 \%$ dengan perbandingan 1:10, diaduk agar semua serbuk tercampur dengan pelarut secara homogen. Maserasi dilakukan selam 5 hari dengan sekali dalam sehari diaduk. Setelah 5 hari maserasi kemudian di saring hingga di dapatkan ekstrak cair.

Pembuatan Spray Foot sanitizer Pembuatan spray Foot sanitizer mengacu pada penelitian Riyanta dan Febriyanti, (2018) pada formulas yang tercantum di tabel 1 berikut ini:

Formula \%

\begin{tabular}{|c|c|c|c|}
\hline \multirow[b]{2}{*}{ Bahan } & \\
\hline & I & II & III \\
\hline Ekstrak jahe & 45 & 35 & 25 \\
\hline Ekstrak biji kopi & 25 & 35 & 45 \\
\hline Gliserin & 10 & 10 & 10 \\
\hline Metil paraben & 0,2 & 0,2 & 0,2 \\
\hline Etanol $70 \%$ ad & $50 \mathrm{~mL}$ & $50 \mathrm{~mL}$ & $50 \mathrm{~m}$ \\
\hline
\end{tabular}


c. Evaluasi Sediaan

Pengamatan organoleptis yang dilakukan untuk melihat perubahan fisik dari sediaan meliputi bentuk, bau dan warna menggunakan indera.

d. Uji fisik sediaan

Uji pH dengan $\mathrm{pH}$ Meter (HANA), uji berat jenis dengan metode piknometer (Pyrex) dan uji viskositas dengan metode otswald.

III. HASIL DAN PEMBAHASAN

\section{1) Uji Organoleptis}

Evaluasi ini dilakukan bertujuan untuk mengetahui bentuk bau, warna dan rasa dari sediaan. Berdasarkan hasil uji organoleptis didapatkan hasil bentuk sediaan cair jernih, berwarna kekuningan dan berasa dingin ketika digunakan.

\section{2) Uji pH}

Uji $\mathrm{pH}$ bertujuan untuk menyesuaikan ph sediaan dengan $\mathrm{pH}$ kulit, sehingga ketika saat digunakan kulit tidak mengalami iritasi. $\mathrm{pH}$ kulit menurut voigt (1994) yaitu 4-6,5. Hasil ini sejalan dengan penelitian dari Fitriansyah dkk, 2016; Rachmaniar dkk., 2015; Iswandana dan Sihombing, 2017. Berdasarkan hasil uji yang telah dilakukan $\mathrm{pH}$ sediaan yang didapat adalah 6.

3) Uji Berat Jenis

Tujuan dilakukan uji berat jenis adalah untuk mengetahui berat jenis sediaan Spray foot sanitizer yang dibuat. Data yang diperoleh dari hasil penelitian dapat dilihat pada tabel berikut ini :

Tabel 2. Hasil Uji Bobot Jenis

\begin{tabular}{cc}
\hline Formula & Berat Jenis \\
\hline I & $0,9408 \mathrm{~g} / \mathrm{ml}$ \\
II & $0,9452 \mathrm{~g} / \mathrm{ml}$ \\
III & $0,954 \mathrm{~g} / \mathrm{ml}$ \\
\hline
\end{tabular}

Berdasarkan data di atas menunjukan bahwa formula 1 memiliki berat jenis yang paling kecil dengan rata-rata $0,9408 \mathrm{~g} / \mathrm{ml}$ dan berat jenis paling besar yaitu pada formula 3 dengan ratrata $0,954 \mathrm{~g} / \mathrm{ml}$. Hal ini disebabkan ekstrak kopi pada formula 3 memiliki persentasi lebih besar dibandingkan dengan ekstrak jahe, dimana kepekatan ektrak kopi berpengaruh terhadap berat jenis sediaan footsanitizer.

\section{4) Uji viskositas}

Uji viskositas dilakukan menggunakan alat viskometer ostwald yang bertjuan untuk mengetahui tingkat kekentalan suatu sediaan.
Tabel 3. Hasil uji viskositas

\begin{tabular}{cc}
\hline Formula & Viskositas \\
\hline I & $2,152 \mathrm{Cp}$ \\
II & $2,2523 \mathrm{Cp}$ \\
III & $2,3013 \mathrm{Cp}$ \\
\hline Cp: Satuan viskositas centipois
\end{tabular}

Berdasarkan tabel di atas menunjukan bahwa formula 1 memiliki viskositas paling kecil dibandingkan dengan formula 2 dan 3 . Hal ini berbanding lurus dengan hasil uji berat jenis dimana semakin kecil nilai berat jenis maka viskositas juga akan semakin kecil. Pada sediaan footsanitizer viskositas dan berat jenis yang rendah akan memudahkan saat sediaan disemprotkan pada kulit. Hal ini ini dipengaruhi oleh perbedaan konsentrasi ekstrak yang ditambahkan. Ekstrak kopi memiliki viskositas dan bobot jenis yang lebih tinggi dibandingkan ekstrak jah yang diperoleh. Ekstrak jahe lebih bening kondisi fisiknya dibandingkan kopi.

5) Uji aktivitas antibakteri

Aktifitas daya hambat bakteri dapat dilihat dari terbentuknya zona bening disekitar sumuran pada media MHA yang disebut sebagai zona hambat.

\section{Luas Daya Hambat}

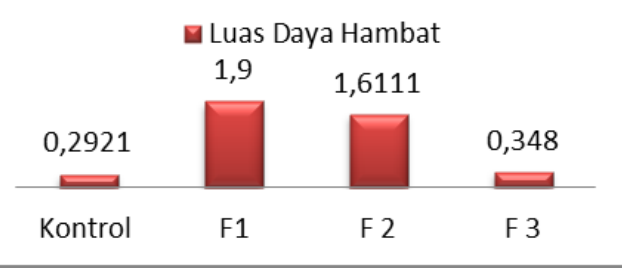

Gambar 1. Luas daya hambat sediaan terhadap S. Epidermis

Pada formula 1 diperoleh luas zona hambat sebesar $1,9000 \mathrm{~cm}^{2}$, formula 2 diperoleh luas zona hambat sebesar 1,6111 $\mathrm{cm}^{2}$, formula 3 diperoleh luas zona hambat sebesar $0,384 \mathrm{~cm}^{2}$, dan kontrol positif dengan menggunakan etanol $70 \%$ diperoleh hasil sebesar 0,2921 cm2.

Formula 1,2 dan 3 memiliki kemampuan daya hambat terhadap bakteri S.epidermis lebih besar dari pada kontrol positif. Selain perbedaan ekstrak, kekentalan dan kerapatan suatu larutan akan sangat berpengaruh terhadap daya difusi zat aktif. Semakin tinggi kerapatan suatu larutan akan semakin kecil daya difusi yang dihasilkan. Sebaliknya, semakin rendah suatu kerapatan sediaan akan semakin tinggi daya difusi yang dihasilkan.

Formula 1 memiliki daya hambat yang paling tinggi dibandingkan formula 2 dan 3 . Formula 1 memiliki kandungan ekstrak jahe tertinggi sehingga memiliki daya hambat yang 
palin tinggi. Jahe terbukti memiliki aktivitas antibakteri yang cukup efektif ${ }^{911}$

\section{KESIMPULAN}

Hasil penelitian yang telah dilakukan dapat diambil kesimpulan sebagai berikut:

1. Adanya daya hambat sediaan foot sanitizer kombinasi ekstrak biji kopi dan rimpang jahe.

2. Formula daya hambat sediaan foot sanitizer kombinasi ekstrak biji kopi dan rimpang jahe yang paling baik terdapat pada formula 1 .

\section{UCAPAN TERIMA KASIH}

Peneliti mengucapkan terimakasih kepada Politeknik Harapan Bersama karena telah membantu membiayai penelitian ini.

\section{REFERENSI}

[1] Ara, K., Hama, M., Akiba, S., Koike, K., Okisaka, K., Hagura, T., Kamiya T., Tomita, F., 2006, Foot odor due to microbial metabolism and its control, Can. J. Microbiol., 52, 357-364.

[2] Riyanta, A. B., Febriyanti,R. 2018. Pengaruh Kombinasi Ekstrak Biji Kopi Dan Rimpang Jahe Terhadap Sifat Fisik Sediaan Foot Sanitizer Spray. Journal Parapemikir

[3] Riyanta, A. B., \& Nurniswati, N. (2016, May). Adsorpsi Minyak Jelantah Menggunakan Karbon Aktif Dan Serbuk Kopi Pada Pembuatan Sabun Padat Ramah Lingkungan. In Prosiding Seminar Nasional Iptek Terapan (Senit) 2016 Pengembangan Sumber Daya Lokal Berbasis Iptek (Vol. 1, No. 1).

[4] Benjamin DT. (2010). Introduction To Hand Sanitizers Tersedia. http://www.antimicrobialtestlaboratories.com /information_about_handsanitizers.html. Diakses Tanggal 19 Maret 2015.

[5] Santoso, J. 2018. Optimasi Formula Krim Ekstrak Poliherbal Sebagai Antibakteri Dengan Kombinasi Gliserin, Sorbitol Dan Propilenglikol Sebagai Humektan. Universitas Setia Budi. Surakarta

[6] Voigt. 1984. Buku Ajar Teknologi Farmasi. Diterjemahkan oleh Soendani Noeroto. S.,UGM Press, Yogyakarta
[7] Rachmaniar, R., Kartamihardja, H., Sari, N. N., Barata, T., 2015. Formulasi Dan Evaluasi Gel Aromaterapi Minyak Atsiri Bunga Kenanga (Cananga Odorata) Sebagai Antidepresi. JSTFI Indonesian Journal of Pharmaceutical Science and Technology Vol.IV, No.2.

[8] Fitriansyah, Sani Nurlaela., Wirya, Sohadi., Hermayanti, Cici., 2016. Formulasi Dan Evaluasi Spray Gel Fraksi Etil Asetat Pucuk Daun Teh Hijau (Camelia Sinensis [L.] Kuntze) Sebagai Antijerawat. PHARMACY, Vol.13 No. 02

[9] Fathia, Sarah. 2011. Aktivitas Antimikroba Ekstrak Jahe (Zingiber Officinale Roscoe) Terhadap Beberapa Bakteri Patogen. Skripsi. Fakultas Teknologi Pertanian Institut Pertanian Bogor

[10] Iswandana, Raditya., Sihombing, Lidya KM.,2017. Formulasi, Uji Stabilitas Fisik, dan Uji Aktivitas Secara In Vitro Sediaan Spray Antibau Kaki yang Mengandung Ekstrak Etanol Daun Sirih (Piper betle L.). PharmSciRes Vol. 4 No. 3)

[11] Megasari, Ni Putu., Fatimawali, Bodhi, Widdhi., 2015. Uji Aktivitas Antibakteri Ekstrak Etanol Rimpang Jahe Merah (Zingiber Officinale Rosc. Var Rubrum) Terhadap Bakteri Klebsiella Pneumoniae Isolat Sputum Penderita Bronkitis Secara In Vivo. PHARMACON Jurnal Ilmiah Farmasi - UNSRAT Vol. 4 No. 3 Agustus 2015 ISSN 2302 - 2493

[12] Pelczar, M.J. and R.D. Reid. 1979. Microbiolgi Concept and Application. Mc. Graw- Hill Book Co. New York. 396 pp. 